\title{
VARIABILITY OF APPARE NTLY HOMOGENEOUS SOILSCAPES IN SÃO PAULO STATE, BRAZIL: II. QUALITY OF SOIL MAPS ${ }^{(1)}$
}

\author{
M. van den BERG ${ }^{(2)} \& J$. B. OLIVEIRA ${ }^{(3)}$
}

\begin{abstract}
SUMMARY
The quality of semi-detailed (scale 1:100.000) soil maps and the utility of a taxonomically based legend were assessed by studying 33 apparently homogeneous fields with strongly weathered soils in two regions in São Paulo State: Araras and Assis. An independent data set of 395 auger sites was used to determine purity of soil mapping units and analysis of variance within and between mapping units and soil classification units. Twenty three soil profiles were studied in detail. The studied soil maps have a high purity for some legend criteria, such as B horizon type ( $>90 \%$ ) and soil texture class $(>80 \%)$. The purity for the "trophic character" (eutrophic, dystrophic, allic) was only 55\%in Assis. It was $\mathbf{8 8} \%$ in Araras, where many soil units had been mapped as associations. In both regions, the base status of clay-textured soils was generally better than suggested by the maps. Analysis of variance showed that mapping was successful for "durable" soil characteristics such as clay content ( $>\mathbf{8 0} \%$ of variance explained) and cation exchange capacity ( $\geq 50 \%$ of variance explained) of $0-20$ and $60-80 \mathrm{~cm}$ layers. For soil characteristics that are easily modified by management, such as base saturation of the $0-20 \mathrm{~cm}$ layer, the maps had explained very little $(\leq 15 \%)$ of the total variance in the study areas. Intermediate results were obtained for base saturation of the $60-80 \mathrm{~cm}$ layer (56\% in Assis; $42 \%$ in Araras). Variance explained by taxonomic groupings that formed the basis for the legend of the soil maps was similar to, often even smaller than, variance explained by mapping units. The conclusion is that map boundaries have been very carefully located, but descriptions of mapping units could be improved. In future mappings, this could possibly be done at low cost by (a) bulk sampling to remove short range variation and enhance visualization of spatial patterns at distances > $100 \mathrm{~m}$; (b) taking advantage of correlations between easily measured soil characteristics and chemical soil properties and, (c) unbending the link
\end{abstract}

\footnotetext{
(1) Part of Doctor's thesis of the first author. Received for publication in april 1999 and aproved in april 2000.

(2) Guest Researcher, Wageningen University, Dept. Environmental Sciences, Laboratory of Soil Science and Geology; P.O. Box 37, 6700 AA Wageningen, Netherlands; on leave of Directorate General of International Co-operation, Netherlands; E-mail: Maurits.vandenBerg@algemeen.beng.wau.nl.

(3) Visiting Professor, Universidade Estadual de Campinas (UNICAMP). Rua Coronel Quirino 1457/42. CEP 13025-002 Campinas (SP). E-mail: bertoldo@agr.unicamp.br.
} 


\begin{abstract}
between legend criteria and a taxonomic system. The maps are well suited to obtain an impression of land suitability for high-input farming. Additional field work and data on former land use/management are necessary for the evaluation of chemical properties of surface horizons.
\end{abstract}

Index terms: soil variability, map quality, sampling, Latosols.

\author{
RESUMO: VARIABILIDADE DE PEDO-PAISAGENS APARENTEMENTE \\ HOMOGÊNEAS NO ESTADO DE SÃO PAULO, BRASIL: \\ II. QUALIDADE DE MAPAS DE SOLOS
}

\begin{abstract}
Avaliou-sea qual idade demapas de sol o semi detal hados (escala 1:100.000) bem como a utilidade de uma legenda baseada na taxonomia, por meio de um estudo de 33 glebas aparentementehomogêneas com sol os fortementeintemperizados de duas regiões no estado deSão Paulo: Araras eAssis. Nessas gl ebas, anal isou-seum conjunto independentededados de395 Iocais, com amostras desol o col etadas a trado para determinar a pureza das unidades de mapeamento de solo e para analisar a variância entre as unidades de mapeamento e unidades taxonômi cas edentro delas. Vinteetrês perfis desol os foram estudados. Os mapas de solo estudados apresentaram el evada pureza em relação a alguns critérios, tais como tipo de horizonte B (>90\%) e classe de textura (>80\%). A pureza para o caráter trófico (eutrófico, distrófico, álico) do mapa de Assis era de apenas 55\%, contra 88\% em Araras, ondemuitas uni dades desol o tinham si do mapeadas como associações. Em ambas as regiões, o caráter trófico dos solos argi losos foi geral mente mel hor do que indicado pel os mapas. Anál ise de variância mostrou que o mapeamento resolveu parte consi derável da variância de características "duráveis", como teor de argila (>80\%) e capacidade de troca catiônica ( $\geq 50 \%$ ) das camadas de 0-20 e 60-80 cm de profundidade. No caso de características que podem ser modificadas facilmente por meio do manejo, tal como a saturação por bases na camada de $0-20$ cm, o mapeamento resol veu uma partemuito pequena $(\leq 15 \%)$ da variância total nas áreas estudadas. Resultados intermediários foram obtidos para saturação por bases na camada de $60-80 \mathrm{~cm}$ (56\%, em Assis; 42\%, em Araras). A variância resolvida por agrupamentos taxonômicos, que formaram a base para a legenda dos mapas, foi si milar e freqüentemente inferior à variância resolvida por unidades de mapeamento. Concluiu-se que as delimi tações nos mapas foram localizadas cuidadosamente, mas as descri ções das unidades de mapeamento poderiam ser melhoradas. É possível que isso possa ser feito a bai xo custo em mapeamentos futuros por meio de (a) col eta de amostras compostas para remover a variação a curta distância e mel horar a visualização de padrões espaciais a distâncias > 100 m; (b) tirar mai or provei to de correlações existentes entre características de determinação si mples e propriedades quími cas dos sol os e (c) abrandar a ligação entre os critéri os usad os nas legendas eum sistema taxonômi co. Os mapas apresentaram-seúteis para obter uma impressão da aptidão das terras para a agri cultura mecanizada. Trabal ho de campo adicional eregistros históricos de uso/ manejo foram necessários para a avaliar as propriedades quími cas dos horizontes superficiais dos solos.
\end{abstract}

Termos deindexação: variabilidadedesolos, qualidadedemapas, amostragem, Latossol os.

\section{INTRODUCTION}

Soil maps are increasingly being used for purposes their makers never had in mind. They are linked to GIS with overlays of other maps and "representative profiles" are used to represent mapping units in automated land evaluation studies etc... (Koning \& Diepen, 1992; Rötter \& Dreiser, 1994; Mantel \& Engelen, 1997). These new applications of soil maps call for increased awareness with regard totheir quality. Thequality of soil maps is traditionally taken care of by using experienced, well-trained surveyors, optimizing observation density, sampling schemes and laboratory methods. The final result should betested with an independent data set. This is not often donebecause it is expensiveand, possibly, because the makers are so confident of their product that they believe additional tests are unnecessary. 
Since the 1980s, many research efforts have been devoted to optimizing sampling schemes and interpolation techniques for isorithmic maps (Webster \& Oliver, 1990, Burrough \& McDonnell, 1998). These techniques are especially useful for detailed studies (scale $>1: 20.000$ ) with a clear objective (e.g. the depth of a toxic layer). There has been much less research attention to the quality of so-called multi-purpose maps that use a choropleth representation. Several apparently straightforward methodologies are established (Beckett \& Webster, 1971; Marsman \& Gruijter, 1986; Oberthür et al., 1996), but not often applied. For Brazil, where only a minor part has been mapped at a larger scalethan 1:500.000, just one reference was found of a study on soil map quality using independent data: Berg \& Klamt (1997) compared soils in seven fields in the Passo F undo Region (RS) with a 1:1 M map and found none of them correctly described by the legend, although in most cases discrepancies werenot severe.

The quality of choropleth maps cannot be indicated by a single rating. The ultimate criterion for the user is that therisk of taking a wrong decision based on map information should be small. In modern applications this implies that outcomes of models (e.g. for crop growth, erosion hazard) using the map as a source of input data may not giveerrors beyond acceptable proportions. This can only be assessed when the application of the map is clear a priori, which is typically not the case for multipurpose maps. Additional criteria to be considered include: (a) user-friendliness, which may be indicated by indices of complexity (Bregt \& Wopereis, 1990); (b) the purity of mapping units and (c) the heterogeneity of mapping units. Of these, only the latter two will be addressed in this study.

\section{Purity}

Map purity is an indication of the degree of correspondence between what is indicated on the map and what is actually present in the field. It can be defined as the fraction or percentage of independently sampled sites that exactly match the legend description of the corresponding mapping unit. Purity can be determined either for the soil map as a whole, or for separate legend criteria.

The Soil Survey Manual of 1951 (Soil Survey Staff, 1951) states that a mapping unit contains up to about 15 percent of impurities. The 1993 edition (Soil Survey Staff, 1993) uses more nuances, by considering rather vaguely defined "similar", "dissimilar", "very contrasting", "nonlimiting" and "limiting" soils. I ndicativetotal amounts of inclusions (an often used euphemistic term for impurities) that are generally not exceeded are $50 \%$ of similar soils, $25 \%$ of dissimilar nonlimiting soils, $15 \%$ of dissimilar limiting soils and $10 \%$ of dissimilar limiting very contrasting soils (Soil Survey Staff, 1993).
The review of Beckett \& Webster (1971) reports observed impurity values ranging from $4 \%$ to $83 \%$, with a median of $50 \%$ for soil series, but impurity estimates provided by Soil Survey reports are often in the 5 to $15 \%$ range. Brown \& Huddleston (1991) suggested that this contrast reflects perhaps some disinclination to report the truth, but it seems more likely that impurities are underestimated because Soil Survey Staff (1993) suggests a biased method, namely to estimate the actual amount of inclusions from observations made during the survey and make adjustments in mapping if appropriate.

Marsman \& Gruijter (1984) and Burrough et al. (1971) have argued that the concept of purity has little meaning, because it is conditioned by legend definitions, for example, stating that the soil of a mapping unit has a $\mathrm{pH}$ ranging between 1 and 14 gives $100 \%$ purity, but $0 \%$ information. Nevertheless, information on purity, in combination with other criteria, is thought to be hel pful; not just for quantifying mapping errors, but rather for assessing the balance between the level of generalization in the legend of a map and real world complexity. Purity studied for individual legend criteria helps judging whether adopted class boundaries are appropriate, or whether legend criteria are impracticable because of large shortrange variability.

\section{Homogeneity of mapping units}

A simple and powerful method to estimate the homogeneity of mapping units is by determining "within mapping unit variance" (Beckett \& Webster, 1971; Gruijter \& Marsman, 1985). It can be calculated for individual soil characteristics with a one-way analysis of variance. Multivariate methods provide more information, but are more difficult to interpret. Oncethe within mapping unit variance is known, third parties can use this information for error analysis. Many soil scientists use the coefficient of variation (CV) to indi catehomogeneity of mapping units (Beckett \& Webster, 1971; Wilding \& Drees, 1978). CV is defined as thestandard deviation divided by theaveragevalue, usually expressed as percentage.

Some soil characteristics tend to present more variability within mapping units than others. Wilding \& Drees (1978) provide the following indicative ranges based on compiled information from published and unpublished sources:

- least variable properties (CV commonly <15\%), colour hue and value, $\mathrm{pH}$;

- moderately variable properties (CV commonly between 15 and 35\%), particle size separates (sand, clay, silt content), cation exchange capacity, base saturation;

- most variable properties (CV commonly > 35\%), soil colour chroma, exchangeable cations, organic matter content. 
Legends of soil maps are often based on taxonomic criteria. Analysis of variance of soil characteristics within and between taxonomic units can be used, for example, to indicate the appropriateness of a soil classification system to separate land evaluation units. The smaller the "within-class variance" of relevant soil characteristics, the more efficiently the classification system can be used to "translate" soil classes to suitability classes.

The objectives of this study are: (1) to quantify the heterogeneity of apparently homogeneous mapping units with strongly weathered soils, in terms of purity and resolved variance of soil variables; (2) to assess the utility of the soil maps for agricultural land evaluation; and (3) to suggest possibilities for economically feasible improvements of soil map quality.

\section{MATE RIALS AND METHODS}

\section{Research strategy}

- Soil data from auger samplings [395 sites on 33 apparently homogeneous on-farm fields with sugarcane (Araras and Assis) or soybean/wheat rotation (Assis), as described by Berg \& Oliveira (2000)] were compared with soil maps.

- Map qual ity indices were determined: (1) purity of mapping units for several legend criteria, (2) variance of soil characteristics within mapping units, (3) variance of soil characteristics within soil classification units.

- A detailed identification was done on 23 soil profiles from selected fiel ds for comparison with soil maps and with the more general information from the auger sampling.

\section{Studied soil maps}

In the Araras region, the soil maps used for both selection of "homogeneous" sugarcane fields and comparison with ground truth are in the 1:100.000 sheets of Campinas (Oliveira et al., 1977); Araras (Oliveira et al., 1981) and São Carlos (Prado et al., 1981). In Assis, "homogeneous" sugarcanefiel ds were selected by using the 1:50.000 map of Souza Dias (1985). Soybean/wheat fields were selected using personal information from local farmers and extension workers. Comparison between map information and ground truth in Assis was made with a final draft of the 1:100.000 soil map (Bognola et al., 1996).

All soil maps that formed the basis for this study were elaborated according to the methodology related by Oliveira \& Prado (1984). Map legend criteria follow the concepts and terminology of soil classification as described by Camargo et al. (1986a) and Oliveira et al. (1992). A brief outlinefor relevant soil units is presented in table 1. Engl ish equivalents for Brazilians Soil Science terms were adopted from Oliveira \& Berg (1996). According to the maps, all soils of thestudy areas, except those which are sandy textured throughout, have either a latosolic B horizon or a textural B horizon and low activity clay.

\section{Field and laboratory methods}

Auger sampling procedures and methods for determining siteand soil characteristics in the field at 395 sites are described by Berg \& Oliveira (2000).

The 23 sites for profile pits were selected after the auger sampling, in order to represent the soil of the selected field. The sites were on land with slopes $<5 \mathrm{~cm} \mathrm{~m}^{-1}$, because they were also used for studies on soil-water relations in situ (Berg, 1996, 1997). F or the same reason, the sites had to be accessible to Iorries. Soil profiles were described according to the Guidelines for Soil Profile description (FAO, 1977). Samplesfrom each horizon weretaken tothelaboratory.

Laboratory methods, according to Raij \& Quaggio (1983) and Camargo et al. (1986b) are the same as those that were used for the elaboration of the studied soil maps and the analyses were done in the same laboratories, by technical staff. Analysis methods for auger samples $(0-20 \mathrm{~cm}$ and $60-80 \mathrm{~cm}$ layers) are resumed by Berg \& Oliveira (2000). The following analyses were done additionally, on selected samples from $B$ horizons of all profiles and a few auger samples of the $60-80 \mathrm{~cm}$ layer in each field: total $\mathrm{Fe}_{2} \mathrm{O}_{3}, \mathrm{Al}_{2} \mathrm{O}_{3}, \mathrm{TiO}_{2}$, and $\mathrm{SiO}_{2}$, by spectrophotometer after destruction with sulphuric acid and sodium hydroxide (according to Camargo et al., 1986b).

\section{Classification}

The soil at each sampling site was classified according tothemap legend criteria. An unambiguous classification of auger samplings was not always possible. The foll owing simplifications were applied: (1) analytical data of the $60-80 \mathrm{~cm}$ layer were consider ed representative for the B horizon; (2) field records up to $100 \mathrm{~cm}$ depth and clay ratio between sampled depths [(clay content 0-20 cm layer) $\div$ (clay content $60-80 \mathrm{~cm}$ layer)] were used to identify textural $\mathrm{B}$ horizons because clay skins cannot often be identified on auger samples; (3) only colour was used to separate classes at the second level because $\mathrm{Fe}_{2} \mathrm{O}_{3}$ and $\mathrm{Al}_{2} \mathrm{O}_{3}$ contents were measured on few samples only; (4) the diagnostic difference in col our between the $A$ horizon and the horizon just above the weathered rock could not be checked in deep soils(4). Therefore, colour comparisons were made between the 0-20 and 60-80 cmlayers. No distinction was made between chernozemic and prominent $A$ horizons.

(4) In practice, this criterion is usually not applied in Brazilian soil surveys. 
Table 1. Summarized taxonomic definitions of map legend units with strongly weathered soils in the study areas. Definitions according to Camargo et al. (1986a) and Oliveira et al. (1992)

\section{Soil classes at first two hierarchical levels}

LATOSOLS: Mineral soils, not hydromorphic, with latosolic B horizon following any diagnostic A horizon. Subdivisions according to type of Iatosolic B.

DUSKY RED LATOSOLS: Dusky red to dark reddish brown (B horizon with hue redder than 4YR, value $\leq 3$, chroma $\leq 6)$; related to high content of $\mathrm{Fe}_{2} \mathrm{O}_{3}\left(180-400 \mathrm{~g} \mathrm{~kg}^{-1}\right)^{(1)}$, strong magnetic attraction, $\mathrm{Ki}$ (molecular ration $\mathrm{SiO}_{2} / \mathrm{Al}_{2} \mathrm{O}_{3}$ ): 0.2-2.0.

DARK RED LATOSOLS: Dark red to dark reddish brown, related to medium content of $\mathrm{Fe}_{2} \mathrm{O}_{3}$ $\left(80-180 \mathrm{~g} \mathrm{~kg}^{-1}\right)^{(1)}$, weak magnetic attraction; $\mathrm{Ki}$ 0.2-2.2.

RED-YELLOW LATOSOLS: Red, yellowish red to strong brown, related to small content of $\mathrm{Fe}_{2} \mathrm{O}_{3}$ $\left(70-110 \mathrm{~g} \mathrm{~kg}^{-1}\right)^{(1)}$; virtually no magnetic attraction; Ki normally $<1.5$; molecular ratio $\mathrm{SiO}_{2} /\left(\mathrm{Fe}_{2} \mathrm{O}_{3}+\mathrm{Al}_{2} \mathrm{O}_{3}\right)<1.4$

STRUCTURED DUSKY RED EARTHS: Mineral soils, non hydromorphic, clayey, following any diagnostic A horizon; with textural B horizon, having moderate to strong blocky or compound prismatic structure, with associated clay skins that are at least common and moderately developed. Low activity clay; only small clay increase from A to B horizon. Dark reddish brown, dusky red, reddish brown, dark red to red colours; $\mathrm{Fe}_{2} \mathrm{O}_{3} \geq 150 \mathrm{~g} \mathrm{~kg}^{-1} ; \mathrm{TiO}_{2} \geq 15 \mathrm{~g} \mathrm{~kg}^{-1}$; weak to no magnetic attraction; $\mathrm{Ki}$ index 0.9-2.3.

PODZOLICS: Mineral soils, not hydromorphic; any A and, or, E horizon; not plinthic; with a textural B horizon that lacks the distinctive features of Planosols. N.B. According to the soil maps, all Podzolics of the study regions have Iow clay activity (i.e. CEC $<240 \mathrm{mmolc} \mathrm{kg}^{-1}$ ).

DARK RED PODZOLICS: Red to dark reddish brown;

$37.5+\left(0.0625^{*} \mathrm{clay}\left(\mathrm{g} \mathrm{kg}^{-1}\right)\right) \leq \mathrm{Fe}_{2} \mathrm{O}_{3} \leq 150 \mathrm{~g} \mathrm{~kg}^{-1}$ and $\mathrm{TiO}_{2} \leq 17 \mathrm{~g} \mathrm{~kg}^{-1}$

RED YELLOW PODZOLICS: Red, yellowish red to strong brown;

$\mathrm{Fe}_{2} \mathrm{O}_{3} \leq 37.5+(0.0625 * \mathrm{clay}) \mathrm{g} \mathrm{kg}^{-1}$.

QUARTZOSE SANDS: Soils with AC profile formed on quartzose sands.

Subdivisions at third level:

Trophic character: eutrophic (e): base saturation $\geq 50 \%$; dystrophic (d): base saturation $<50 \%$ and $\mathrm{Al}$ saturation $<50 \%$; allic (a): Al saturation $\geq 50 \%$;

A horizon: weak $(w)$ : weakly structured or structureless, with colour value moist $>5$ and organic $C$ content $<5.8 \mathrm{~g} \mathrm{~kg}^{-1}$, moderate $(\mathrm{m})$ : as ochric of $\mathrm{FAO} / \mathrm{U}$ nesco (1990), excluding weak A; prominent (p): as umbric of FAO/Unesco (1990), chernozemic (c,): as mollic of FAO/U nesco (1990);

Texture: sandy (s): sand + loamy sand of FAO (1977); clayey (c): $350 \leq$ clay content $\leq 600 \mathrm{~g} \mathrm{~kg}^{-1}$; very fine clayey $(\mathrm{fc})$ : clay content $>600 \mathrm{~g} \mathrm{~kg}^{-1}$; medium $(\mathrm{m})$ : rest group. Some units of the maps of the Araras region distinguish sandy medium $\left(\mathrm{ms}_{\mathrm{s}}\right.$ ): [clay content $<200 \mathrm{~g} \mathrm{~kg}^{-1}$ or (clay cont. $<250 \mathrm{~g} \mathrm{~kg}^{-1}$ and content of coarse sand $>$ fine sand)] and fine medium $(\mathrm{mf})$ : finer than $\mathrm{ms}$. For Podzolics, texture class of both $A$ (or E) and Bt horizons are indicated, separated by "/", e.g. s/c : sandy textured A or E and clayey B horizon.

(1)Applied to soils with clay content $\geq 350 \mathrm{~g} \mathrm{~kg}^{-1}$ (clayey texture). For medium textured soils, the $\mathrm{Al}_{2} \mathrm{O}_{3} / \mathrm{Fe}_{2} \mathrm{O}_{3}$ molecular ratio is used as a distinctive criterion; e.g. 3.14 is the upper limit for Dark Red Latosols.

\section{Statistical analysis}

\section{Purity}

Purity for separatelegend criteria of the soil maps was calculated as the percentage of independent observations that match the legend criterion of interest. Total purity was calculated as the percentage of independent observations that match all legend criteria. The independent observations are the 395 auger samplings. These observations are independent in a sense that they were not used to elaboratethestudy maps but, considering theresults of Berg \& Oliveira (2000), observations within fields are not spatially independent. On the 1:100.000 maps, thestudy fields cover no more than a few $\mathrm{cm}^{2}$, and the average distance between neighbouring observation sites of some $300 \mathrm{~m}$ is represented by only $3 \mathrm{~mm}$ on the maps. Sites in each field in Araras are mostly within the same mapping unit. This was generally not the case in Assis, were one map was used for field selection and another one for "ground truthing". 
For Araras, the legend printed on the map sheets specifies for all units of Red Yellow Latosols that trophic character is allic; but the accompanying report describes the concepts of these units as "allic or dystrophic". The latter description was used for purity analysis.

\section{Analysis of variance}

The SYSTAT (Systat, 1985) package was used to execute one-way analysis of variance of soil characteristics within and between soil mapping units, and soil classification units for the observations of the overall sampling. Soil classification units were defined by application of the legend criteria of the soil maps (Table 1) to theindependent observations of the overall sampling.

Analysis of variance was done at three levels of generalization (Table 1), both by mapping units as well as by soil classification units. Groupings with less than five occurrences were lumped together with the nearest grouping at the lowest possible level of generalization.

Pooled coefficients of variance (CV) were calculated for each characteristic as the square root of pool ed within unit variance divided by the regional average; in order to compare homogeneity of mapping units with theindicative ranges of Wilding \& Drees (1978).

\section{RESULTS}

\section{Purity of soil maps}

In Araras, for 11 sites the collected information was insufficient to judge whether or not they corresponded to the map indications; six cases were related to col our (dark red or dusky red), and five to the presence or not of a textural B. To avoid complications it was decided to arbitrarily consider six of these cases as "correctly mapped" and five as impurities.

Average purity of mapping units of the Araras region was estimated as $81 \%$ at the first level, 60 at the second level and 41 at the third level of generalization; $23 \%$ (38 cases) of the sampled sites did not match the description of any of the legend units that were considered by the map, for example, eutric Dark Red Latosols. Purity estimates and discrepancies at the third level of generalization are given in table 2. The most frequent sources of discrepancy are: (1) colour of the B horizon, especially of soils mapped as Dark Red Latosols; (2) type of A horizon, which was often mapped as moderate but found too thick and dark, especially in medium textured Red Yellow Latosols; and (3) type of B horizon of soils that were mapped as Red Yell ow Podzolics.
For the Assis region, purity was $90 \%$ at the first level, 86 at the second level and 44 at thethird (unit) level of generalization. Purity estimates and discrepancies at the third level of generalization are given in table 3. The dominant source of discrepancy in the Assis region was trophic character (eutrophic, dystrophic, allic). In 58 cases (25\%) trophic character was "better", i.e. higher base saturation or lower Al saturation, than indicated on the map; in 45 cases (20\%) it was worse. Hence, the purity for trophic character in the Assis region is $(100-25-20) \%=55 \%$. Note that the legend criteria with respect to the trophic character are narrower for the map of the Assis region than for the Araras region (with 88\% purity for trophic character), where most mapping units are associations.

The results (Table 3 ) suggest that the type of $A$ horizon was an unimportant source of impurity in the Assis region. According to the map, all soils in the Assis region are supposed to have a moderate $A$ horizon. However, morethan $50 \%$ (118 cases) of the sampled A horizons of this region met the colour, thickness and organic matter requirements for chernozemic or prominent A's, but showed too little difference in colour with the underlying horizons.

Comparison of soil map indications with the 23 detailed soil profile descriptions is summarized in table 4 for the Araras region and in table 5 for the Assis region. Results confirm the principal causes of discrepancy. Two profiles from Araras and two others from Assis had a trophic character (class) at $60-80 \mathrm{~cm}$ depth which was different from that of underlying horizons, i.e. the $60-80 \mathrm{~cm}$ layer was not al ways representativefor "theB horizon". In profile 28 (Table 5), the trophic character changed below $125 \mathrm{~cm}$. Whether or not this change is diagnostic was not formalized when the maps were elaborated. The "new" Brazilian system of soil classification (EMBRAPA, 1999) uses the major part of the upper $100 \mathrm{~cm}$ of the $B$ horizon (including transitional BA) as a criterion, which would classify this soil as eutrophic.

Comparison of purity results with indicative figures of the Soil Survey Manual (Soil Survey Staff, 1993) is ambiguous, since the terms "similar", "limiting" and "strongly contrasting" are not objectively defined. They depend on the expectations of the user of the map. Using the criteria of the Land Suitability study of Oliveira \& Berg $(1983,1985)$ for theAraras sheet, thefollowing cases could beconsidered as "dissimilar limiting": soils with textural B horizon instead of Latosolic B (related to erosion hazard); soils with inferior trophic character in the B horizon than indicated (related to natural fertility and Altoxicity) and soils with sandy instead of medium or clayey texture (related to water availability). This would give 25 cases (15\%) of dissimilar limiting impurities in Araras. In Assis, 48 cases (21\%) would be considered dissimilar limiting. Of these, 17 (7\%) were allic where eutrophic was indicated. 
Table 2. Purity analysis for Araras

\begin{tabular}{|c|c|c|c|c|c|c|c|c|c|c|c|c|c|}
\hline \multicolumn{4}{|c|}{ Soil map unit } & \multirow{2}{*}{ Total } & \multirow{2}{*}{ Conf } & \multicolumn{8}{|c|}{$\begin{array}{l}\text { Number of discrepancies with field } \\
\text { observations related with: }\end{array}$} \\
\hline Hierarchical levels $1+2$ & A & TC & txt & & & At & TC+ & TC- & $C+$ & C- & $\mathbf{B} \pm$ & txt+ & txt- \\
\hline Quartzose Sands & - & - & $\mathrm{s}$ & 21 & 15 & - & - & - & - & - & 2 & 6 & \\
\hline Red Yellow Podzolics & $\mathrm{m}$ & $d+a$ & $c+m / c$ & 15 & 3 & 1 & 1 & - & 0 & - & 12 & 0 & 0 \\
\hline Dusky Red Latosols & $\mathrm{m}$ & e & $\mathrm{fc}+\mathrm{c}$ & 35 & 12 & 8 & - & 12 & - & 11 & 0 & - & 1 \\
\hline Dusky Red Latosols & $\mathrm{m}$ & d & $f c+c$ & 1 & 1 & 0 & 0 & 0 & - & 0 & 0 & - & 0 \\
\hline Dark Red Latosols & $\mathrm{m}$ & $a+d$ & $c+f c$ & 18 & 7 & 2 & 4 & - & 0 & 8 & 0 & - & 0 \\
\hline Dark Red Latosols & $\mathrm{m}$ & $a+d$ & $\mathrm{mf}$ & 9 & 3 & 1 & 0 & - & 0 & 5 & 0 & 0 & 3 \\
\hline Red Yellow Latosols & $w+m$ & $a+d$ & ms & 11 & 1 & 3 & 0 & - & 0 & - & 0 & 0 & 10 \\
\hline Red Yellow Latosols & $\mathrm{m}$ & $a+d$ & $\mathrm{mf}$ & 19 & 5 & 12 & 0 & 0 & 6 & - & 0 & 1 & 2 \\
\hline Red Yellow Latosols & $\mathrm{p}$ & $a+d$ & $\mathrm{mf}$ & 16 & 10 & 3 & 1 & - & 4 & - & 1 & 0 & 0 \\
\hline Red Yellow Latosols & $\mathrm{m}$ & $a+d$ & c & 21 & 11 & 2 & 2 & - & 2 & - & 0 & 1 & 5 \\
\hline Totals & & & & 166 & 68 & 32 & 8 & 12 & 12 & 24 & 15 & 8 & 21 \\
\hline Totals (\%) & & & & 100 & 41 & 19 & 5 & 7 & 7 & 14 & 9 & 5 & 13 \\
\hline \multicolumn{14}{|c|}{ Abbreviation soil map units: } \\
\hline \multicolumn{14}{|c|}{$\begin{array}{l}\text { A: type of A-horizon: w weak, m moderate, p prominent; } \\
\text { TC: trophic character: a allic, d dystrophic, e eutrophic; } \\
\text { txt: texture class: fc very fine clayey, c clayey, } \mathrm{m} \text { medium, mf fine medium, ms sandy medium, s sandy. } \\
+: \text { association, e.g. "a+d" is association of allic and distrophic soils; } \\
\text { l : textural differentiation, e.g. "s/m" sandy A or } \mathrm{E} \text { - and medium textured B - horizon. } \\
\text { total: total number of observations; conf: number of observations that match soil map. }\end{array}$} \\
\hline \multicolumn{14}{|c|}{ Abbreviation discrepancies: } \\
\hline \multicolumn{14}{|c|}{$\begin{array}{l}\text { At: Soil map does not match observations with respect to type of A horizon; } \\
\text { TC+ observed trophic character higher than mapped; TC-: trophic character } \\
\text { C+: observed soil colour has redder hue or higher chroma than mapped; } \\
\text { C-: observed soil colour has yellower hue or lower chroma than mapped; } \\
\text { Bt: Soil map does not match observations with respect to type of B horizon; } \\
\text { txt+: observed soil texture finer than mapped; txt-: texture coarser than ma }\end{array}$} \\
\hline
\end{tabular}

\section{Heterogeneity of soil mapping - and classifi- cation - units}

\section{Araras}

Table 6 presents results of the analysis of variance by soil mapping unit and by taxonomic soil unit for the samples of the Araras region. These results can be compared directly with the analysis of variance by fields of Berg \& Oliveira (2000) (Table 1). The soil mapping units explained much of the variance in elevation, clay content, CEC and aluminium saturation of the $60-80 \mathrm{~cm}$ sample. For most other soil characteristics, especially of the 0 $20 \mathrm{~cm}$ layer, the variance accounted for was rather small. Note that soil mapping units generally explained more variance than classification units. Pooled CVs were smaller than theindicativeranges of Wilding \& Drees (1978) for colour chroma and organic carbon content of the $0-20 \mathrm{~cm}$ layer. CVs compared well with the indicative ranges for clay content, $\mathrm{pH}$, sum of exchangeable bases, cation exchange capacity and organic carbon content of the
$60-80 \mathrm{~cm}$ layer. The apparently low CVs of base saturation refer to log transformed values. CVs for the original data are some $40 \%$, i.e. more than the indicative range. CVs for hue are large, but the method to transform Munsell hues to numeric values may not have been the same as used by Wilding \& Drees (1978).

\section{Assis}

Results of the analysis of variance by soil mapping unit and by taxonomic soil class for the samples of theAssis region are presented in table 7 . Theanalysis of variance by field (combining fields with soybeans and sugarcane) is also included in this table.

The variance accounted for by mapping units was not much smaller than the variance accounted for by fields for most characteristics of the $60-80 \mathrm{~cm}$ layer. For the $0-20 \mathrm{~cm}$ layer, much of the variance in clay content, SB, C and CEC was accounted for by the map, but little variance was explained for $\mathrm{pH}$, $\mathrm{V} \%$ and $\mathrm{m} \%$. On the whole, classification units explained as much variance as mapping units. 
Table 3. Purity analysis for Assis

\begin{tabular}{|c|c|c|c|c|c|c|c|c|c|c|c|c|c|c|}
\hline \multicolumn{4}{|c|}{ Soil map unit } & \multirow{2}{*}{ Total } & \multirow{2}{*}{ Conf } & \multicolumn{9}{|c|}{$\begin{array}{c}\text { Number of discrepancies with field } \\
\text { observations related with: }\end{array}$} \\
\hline Hierarchical levels 1+2 & $A$ & $\mathrm{TC}$ & txt & & & Clac & $A+$ & $\mathrm{TC}+$ & TC- & $\mathrm{C}+$ & $\mathrm{C}-$ & $\mathrm{B} \pm$ & txt+ & txt- \\
\hline Dark Red Podzolics & $\mathrm{m}$ & $\mathrm{e}$ & $\mathrm{m} / \mathrm{c}+\mathrm{s} / \mathrm{m}$ & 3 & 1 & 0 & 0 & - & 1 & 0 & 0 & 2 & 0 & 0 \\
\hline $\begin{array}{l}\text { Red Yellow Podzolics, } \\
\text { abruptic }\end{array}$ & $\mathrm{m}$ & $\mathrm{e}$ & $\mathrm{s} / \mathrm{m}$ & 8 & 2 & 0 & 0 & - & 5 & 0 & - & 4 & 0 & 0 \\
\hline Dusky Red Latosols & $\mathrm{m}$ & $\mathrm{e}$ & fc & 59 & 51 & 2 & 2 & - & 2 & - & 2 & 0 & - & 2 \\
\hline Dusky Red Latosols & $\mathrm{m}$ & $d$ & fc & 38 & 9 & 0 & 0 & 29 & 0 & - & 0 & 0 & - & 0 \\
\hline Dusky Red Latosols & $\mathrm{m}$ & $d+a$ & fc & 19 & 10 & 0 & 0 & 9 & - & - & 1 & 1 & - & 1 \\
\hline $\begin{array}{l}\text { Dusky Red Latosols } \\
\text { +Dusky Red Earths }\end{array}$ & $\mathrm{m}$ & $\mathrm{e}$ & fc & 11 & 8 & 0 & 0 & - & 3 & - & 0 & - & - & 0 \\
\hline $\begin{array}{l}\text { Dusky Red Latosols } \\
\text { +Dark Red Latosols }\end{array}$ & $\mathrm{m}$ & d & $f c+c$ & 5 & 1 & 0 & 0 & 3 & 0 & - & 0 & 0 & - & 1 \\
\hline Dark Red Latosols & $\mathrm{m}$ & a & $\mathrm{m}$ & 27 & 17 & 0 & 5 & 5 & - & 0 & 0 & 0 & 0 & 1 \\
\hline $\begin{array}{l}\text { Dark Red Latosols, int. } \\
\text { with Podzolics }\end{array}$ & $\mathrm{m}$ & e & $\mathrm{m}$ & 44 & 2 & 1 & 1 & - & 32 & 0 & 1 & 11 & 4 & 0 \\
\hline $\begin{array}{l}\text { Dark Red Latosols, int. } \\
\text { with Podzolics }\end{array}$ & $\mathrm{m}$ & $d$ & $m+m / c$ & 14 & 0 & 0 & 2 & 11 & 2 & 0 & 0 & 2 & 0 & 1 \\
\hline Red Yellow Latosols & $\mathrm{m}$ & a & $\mathrm{m}$ & 1 & 0 & 0 & 0 & 1 & - & 1 & - & 0 & 0 & 0 \\
\hline Totals & & & & 229 & 101 & 3 & 10 & 58 & 45 & 1 & 4 & 20 & 4 & 6 \\
\hline Totals (\%) & & & & 100 & 44 & 1 & 4 & 25 & 20 & 0 & 2 & 9 & 2 & 3 \\
\hline \multicolumn{15}{|c|}{ Abbreviation soil map units: } \\
\hline \multicolumn{15}{|c|}{$\begin{array}{l}\text { A: type of A-horizon: w weak, m moderate, p prominent; } \\
\text { TC: trophic character: a allic, d dystrophic, e eutrophic; } \\
\text { txt: texture class: fc very fine clayey, c clayey, m medium, s sandy. } \\
+ \text { : association, e.g. "a+d" is association of allic and distrophic soils; } \\
\text { / : textural differentiation, e.g. "s/m" sandy A - and medium textured B - horizon. } \\
\text { total: total number of observations; conf: number of observations that match soil map. }\end{array}$} \\
\hline \multicolumn{15}{|c|}{ Abbreviation discrepancies: } \\
\hline \multicolumn{15}{|c|}{$\begin{array}{l}\text { clac: observed clay activity higher than indicated by soil map; } \\
\text { A+: prominent- or chernozemic A horizon observed but moderate A mapped; } \\
\text { TC+observed trophic character higher than mapped; TC-: trophic character lower than mapped; } \\
\text { C+: observed soil colour has redder hue or higher chroma than mapped; } \\
\text { C-: observed soil colour has yellower hue or lower chroma than mapped; } \\
\text { Bt: Soil map does not match observations with respect to type of B horizon; } \\
\text { txt+: observed soil texture finer than mapped; txt-: texture coarser than mapped; } \\
\text { - : combination not relevant [e.g. trophic character cannot be better (TC+) than eutrophic]. }\end{array}$} \\
\hline
\end{tabular}

For colour chroma, clay content and organic carbon content of the $0-20 \mathrm{~cm}$ layer, CVs are small in comparison with the indicativeranges of Wilding \& Drees (1978). CVs compared well with their indicative ranges for the other characteristics. CV for "untransformed" base saturation percentage was in the range 25 to $35 \%$.

\section{DISCUSSION}

\section{General aspects}

For most soil variables, soil mapping units explained as much variance as classification units, often even more. This is quite remarkable when considering the rather high impurities of the maps for several variables, notably base saturation and Al saturation in Assis. This may reflect some bias on the part of the surveyors, who map natural soil boundaries in the field which are correlated afterwards with taxonomic boundaries with which they do not really correspond. The representativeness of "representative profiles" is another issue of concern.

Broadening definitions increases the purity of a map. The more general use of associations in the legend of the Araras map explains the better purity for the trophic character in the Araras region (Table 2), in comparison with the Assis region 
Table 4. Soil profiles in the Araras region typified according to map unit and ground truth

\begin{tabular}{|c|c|c|c|}
\hline $\begin{array}{l}\text { Field no. } \\
\text { (profile) }\end{array}$ & Legend description of mapping unit & $\begin{array}{c}\text { Confirmed } \\
+/-\end{array}$ & $\begin{array}{l}\text { Comment/reason } \\
\text { of discrepancy }\end{array}$ \\
\hline $\begin{array}{c}01 \\
(1471)\end{array}$ & $\begin{array}{l}\text { Dusky Red Latosol, eutrophic or dystrophic, moderate A, very fine } \\
\text { clayey }\end{array}$ & - & $\begin{array}{l}\text { Textural } \mathrm{B} \text { is present } \\
\mathrm{Fe}_{2} \mathrm{O}_{3}<180 \mathrm{~g} \mathrm{~kg}^{-1}\end{array}$ \\
\hline $\begin{array}{c}02 \\
(1484)\end{array}$ & $\begin{array}{l}\text { Dusky Red Latosol, eutrophic or dystrophic, moderate A, very fine } \\
\text { clayey }\end{array}$ & + & \\
\hline $\begin{array}{c}04 \\
(1480)\end{array}$ & Deep Quartzose sands, moderate A & + & \\
\hline $\begin{array}{c}05 \\
(1479)\end{array}$ & $\begin{array}{l}\text { Red Yellow Latosol, allic or dystrophic, moderate A, sandy-medium } \\
\text { texture }\end{array}$ & - & $\begin{array}{l}\text { Texture is sandy; } \\
\text { A horizon is prominent }\end{array}$ \\
\hline $\begin{array}{c}06 \\
(1470)\end{array}$ & $\begin{array}{l}\text { Red Yellow Latosol, allic or dystrophic, prominent A, fine-medium } \\
\text { texture }\end{array}$ & - & $\mathrm{Al}_{2} \mathrm{O}_{3} / \mathrm{Fe}_{2} \mathrm{O}_{3}<3.14$ \\
\hline $\begin{array}{c}07 \\
(1482)\end{array}$ & $\begin{array}{l}\text { Red Yellow Latosol, allic or dystrophic, prominent A, fine-medium } \\
\text { texture }\end{array}$ & + & \\
\hline $\begin{array}{c}08 \\
(1481)\end{array}$ & Dark Red Latosol, allic or dystrophic, moderate A, clayey texture & + & \\
\hline $\begin{array}{c}10 \\
(1477)\end{array}$ & $\begin{array}{l}\text { Red Yellow Latosol, allic or dystrophic, moderate A, fine-medium } \\
\text { texture }\end{array}$ & - & $\begin{array}{l}\text { A horizon is prominent; } \\
\text { allic } \rightarrow \text { dystrophic } 98 \mathrm{~cm}\end{array}$ \\
\hline $\begin{array}{c}11 \\
(1469)\end{array}$ & Red Yellow L atosol, allic or dystrophic, moderate A, clayey texture & + & \\
\hline $\begin{array}{c}12 \\
(1468)\end{array}$ & Dusky Red Latosols, eutrophic, moderate A, very fine clayey texture & + & \\
\hline $\begin{array}{c}13 \\
(1478)\end{array}$ & $\begin{array}{l}\text { Dark Red Latosol, allic or dystrophic, moderate A, fine-medium } \\
\text { texture }\end{array}$ & + & \\
\hline $\begin{array}{c}14 \\
(1483)\end{array}$ & Dark Red Latosol, allic or dystrophic, moderate A, clayey texture & - & $\begin{array}{l}\mathrm{Fe}_{2} \mathrm{O}_{3}<80 \mathrm{~g} \mathrm{~kg}^{-1} \\
\text { eutrophic below } 95 \mathrm{~cm}\end{array}$ \\
\hline
\end{tabular}

Table 5. Soil profiles in the Assis region typified according to map unit and ground truth

\begin{tabular}{|c|c|c|c|}
\hline $\begin{array}{l}\text { Field no. } \\
\text { (profile) }\end{array}$ & Legend description of mapping unit & $\begin{array}{c}\text { Confirmed } \\
+/-\end{array}$ & $\begin{array}{l}\text { Comment/reason } \\
\text { of discrepancy }\end{array}$ \\
\hline $\begin{array}{c}02 \\
(1509)\end{array}$ & $\begin{array}{l}\text { Dusky Red Latosol, dystrophic or allic, moderate A, very fine clayey } \\
\text { texture }\end{array}$ & + & \\
\hline $\begin{array}{c}03 \\
(1508)\end{array}$ & Dusky Red Latosol, dystrophic, moderate A, very fine clayey texture & - & Trophic character eutrophic \\
\hline $\begin{array}{c}04 \\
(1512)\end{array}$ & Dark Red Latosol, allic, moderate A, medium texture & + & \\
\hline $\begin{array}{c}06 \\
(1507)\end{array}$ & Dusky Red Latosol, dystrophic, moderate A, very fine clayey texture & - & $\begin{array}{l}\text { Trophic character allic (below } \\
100 \mathrm{~cm} \text { ) }\end{array}$ \\
\hline $\begin{array}{c}08 \\
(1511)\end{array}$ & Dark Red Latosol, allic, moderate A, medium texture & + & \\
\hline $\begin{array}{c}11 \\
(1510)\end{array}$ & $\begin{array}{l}\text { Dark Red Latosol, intergrade with Podsolic, eutrophic, moderate A, } \\
\text { medium texture }\end{array}$ & - & Trophic character allic \\
\hline $\begin{array}{c}21 \\
(1504)\end{array}$ & $\begin{array}{l}\text { Dark Red Latosol, intergrade with Podsolic, dystrophic, moderate A, } \\
\text { medium or medium/clayey texture }\end{array}$ & - & $\begin{array}{l}\text { Clayey throughout; Trophic } \\
\text { character eutrophic }\end{array}$ \\
\hline $\begin{array}{c}24 \\
(1505)\end{array}$ & $\begin{array}{l}\text { Dark Red Latosol, intergrade with Podsolic, eutrophic, moderate A, } \\
\text { medium texture }\end{array}$ & + & \\
\hline $\begin{array}{c}25 \\
(1503)\end{array}$ & $\begin{array}{l}\text { Dark Red Latosol, intergrade with Podsolic, eutrophic, moderate A, } \\
\text { medium texture }\end{array}$ & - & $\begin{array}{l}\mathrm{Al}_{2} \mathrm{O}_{3} / \mathrm{Fe}_{2} \mathrm{O}_{3}>3.14 \\
\text { Trophic character allic (below } \\
70 \mathrm{~cm} \text { ) }\end{array}$ \\
\hline $\begin{array}{c}26 \\
(1506)\end{array}$ & Dusky Red Latosol, eutrophic moderate A, very fine clayey texture & + & \\
\hline $\begin{array}{c}28 \\
(1502)\end{array}$ & Dusky Red Latosol, eutrophic moderate A, very fine clayey texture & & $\begin{array}{l}\text { Trophic character dystrophic be } \\
125 \mathrm{~cm}\end{array}$ \\
\hline
\end{tabular}


Table 6. Variance by soil map units and soil taxons for 166 sites in the Araras region

\begin{tabular}{|c|c|c|c|c|c|c|c|c|c|c|c|c|}
\hline \multirow[b]{2}{*}{ Terrain } & \multirow[b]{2}{*}{ Altitude } & \multirow[b]{2}{*}{ SL } & \multicolumn{2}{|c|}{ Colour } & \multirow[b]{2}{*}{ Clay } & \multirow{2}{*}{$\begin{array}{c}\text { pH } \\
\mathrm{KCl}\end{array}$} & \multirow[b]{2}{*}{ SB } & \multirow[b]{2}{*}{ CEC } & \multirow[b]{2}{*}{ m } & \multirow[b]{2}{*}{$\mathbf{v}$} & \multirow[b]{2}{*}{$\mathbf{C}$} & \multirow[b]{2}{*}{$\mathbf{P}$} \\
\hline & & & Hue & Chr & & & & & & & & \\
\hline & $\mathrm{m}$ & $\mathrm{cm} \mathrm{m}^{-1}$ & & & $\begin{array}{c}\mathrm{g} \mathrm{kg}^{-1} \\
0-20 \mathrm{~cm}\end{array}$ & & $-\mathrm{mmol}$ & $\mathrm{kg}^{-1}-$ & — $\%$ & - & $\mathrm{g} \mathrm{kg}^{-1}$ & $\mathrm{mg} \mathrm{kg}^{-1}$ \\
\hline \multicolumn{13}{|c|}{$\%$ of variance accounted for by soil map: } \\
\hline 3 map "orders" & 66 & $15^{(2)}$ & 3 & 7 & 33 & 9 & 14 & 37 & $2^{(2)}$ & $0^{(2)}$ & 22 & $8^{(2)}$ \\
\hline 5 map "classes" & 66 & $15^{(2)}$ & 33 & 14 & 66 & 9 & 30 & 47 & $6^{(2)}$ & $8^{(2)}$ & 25 & $15^{(2)}$ \\
\hline 10 map "units" & 79 & $28^{(2)}$ & 33 & 15 & 84 & 17 & 44 & 62 & $12^{\prime \prime}$ & $14^{(2)}$ & 40 & $39^{(2)}$ \\
\hline \multicolumn{13}{|c|}{ Pooled variance within map units } \\
\hline Variance & 394 & $0.59^{(2)}$ & 73 & 0.62 & $6.3^{(1)}$ & 0.27 & 311 & 328 & $2.7^{(2)}$ & $0.21^{(2)}$ & 16 & $0.52^{(2)}$ \\
\hline C.V. (\%) & 3 & $55^{(2)}$ & 24 & 25 & 23 & 11 & 53 & 28 & $103^{(2)}$ & $12^{(2)}$ & 33 & $69^{(2)}$ \\
\hline \multicolumn{13}{|c|}{$\%$ of variance accounted for by soil taxons classified according to map legend criteria } \\
\hline 3 soil "orders" & 41 & $12^{(2)}$ & 1 & 0 & 41 & 1 & 13 & 33 & $0^{(2)}$ & $0^{(2)}$ & 26 & $10^{(2)}$ \\
\hline 5 soil "classes" & 49 & $12^{(2)}$ & 62 & 1 & 60 & 2 & 28 & 46 & $5^{(2)}$ & $4^{(2)}$ & 40 & $24^{(2)}$ \\
\hline 13 soil "units" & 53 & $10^{(2)}$ & 62 & 14 & 78 & 8 & 47 & 62 & $10^{(2)}$ & $15^{(2)}$ & 51 & $25^{(2)}$ \\
\hline \multicolumn{13}{|c|}{ Pooled variance within taxonomic units } \\
\hline Variance & 886 & $0.74^{(2)}$ & 42 & 0.63 & $8.5^{(1)}$ & 0.30 & 294 & 329 & $2.8^{(2)}$ & $0.21^{(2)}$ & 13 & $0.65^{(2)}$ \\
\hline C.V. (\%) & 4 & $62^{(2)}$ & 18 & 26 & 26 & 12 & 52 & 28 & $105^{(2)}$ & $12^{(2)}$ & 30 & $78^{(2)}$ \\
\hline \multicolumn{13}{|c|}{$60-80 \mathrm{~cm}$} \\
\hline \multicolumn{13}{|c|}{$\%$ of variance accounted for by soil map: } \\
\hline 3 map "orders" & - & - & 3 & 3 & 33 & 14 & 7 & 29 & $9^{(2)}$ & $1^{(2)}$ & 10 & $0^{(2)}$ \\
\hline 5 map "classes" & - & - & 27 & 7 & 65 & 37 & 28 & 37 & $46^{(2)}$ & $27^{(2)}$ & 17 & $12^{(2)}$ \\
\hline 10 map "units" & - & - & 31 & 13 & 84 & 49 & 40 & 50 & $59^{(2)}$ & $42^{(2)}$ & 27 & $12^{(2)}$ \\
\hline \multicolumn{13}{|c|}{ Pooled variance within map units } \\
\hline Variance & - & - & 71 & 1.7 & $7.2^{(1)}$ & 0.13 & 170 & 265 & $1.4^{(2)}$ & $0.19^{(2)}$ & 8 & $0.45^{(2)}$ \\
\hline C.V. (\%) & - & - & 24 & 27 & 21 & 8 & 72 & 35 & $46^{(2)}$ & $13^{(2)}$ & 57 & $39^{(2)}$ \\
\hline \multicolumn{13}{|c|}{$\%$ of variance accounted for by soil taxons classified according to map legend criteria } \\
\hline 3 soil "orders" & - & - & 1 & 1 & 39 & 7 & 10 & 21 & $8^{(2)}$ & $8^{(2)}$ & 16 & $1^{(2)}$ \\
\hline 5 soil "classes" & - & - & 62 & 29 & 57 & 27 & 31 & 32 & $36^{(2)}$ & $22^{(2)}$ & 30 & $17^{(2)}$ \\
\hline 13 soil "units" & - & - & 63 & 34 & 76 & 33 & 50 & 44 & $48^{(2)}$ & $42^{(2)}$ & 33 & $15^{(2)}$ \\
\hline \multicolumn{13}{|c|}{ Pooled variance within taxonomic units } \\
\hline Variance & & & 38 & 1.3 & $10.8^{(1)}$ & 0.16 & 142 & 293 & $1.7^{(2)}$ & $0.19^{(2)}$ & 7.5 & $0.43^{(2)}$ \\
\hline C.V. (\%) & & & 18 & 23 & 26 & 9 & 66 & 36 & $51^{(2)}$ & $13^{(2)}$ & 55 & $39^{(2)}$ \\
\hline
\end{tabular}

(1) multiply values by $10^{3}$. (2) analysis performed after transformation to natural logarithm.

$\mathrm{ALT}=$ el evation above mean sea level. $\mathrm{SL}=$ slope. $\mathrm{SB}=$ sum of exchangeable bases. $\mathrm{CEC}=$ cation exchange capacity. $\mathrm{m}=$ aluminium saturation percentage $\left(100 \mathrm{Al}^{3+} /\left(\mathrm{SB}+\mathrm{Al}^{3+}\right) . \mathrm{V}=\right.$ base saturation percentage $(100 \mathrm{SB} / \mathrm{CEC}) . \mathrm{C}=$ organic carbon content. $\mathrm{P}=$ resin extractable phosphorus.

(Table 3). Both maps were remarkably successful in separating and identifying areas with homogeneous texture. The map (legend) of the Assis region could possibly be more refined concerning this aspect, as it was donefor Araras by separating sandy-medium and fine-medium textured soils.

In Assis, for most variables, the percentage of variance accounted for by mapping increased strongly by refining the level of generalization from the first ("order") to the second ("class") and just slightly from the second to thethird ("unit"). This is remarkable because soils are grouped with respect tothetrophic character and textureat the third level. Analysis of variance for soil taxons shows larger differences between the second and third levels. This seems to be related with the relatively simple geol ogic structure of this region. Mapping units were distinguished according to broad landforms (related with parent material), which show strong correlation with characteristics used for separating soil groupings at the second level (colour and related sesquioxide contents) and at the third level (textural class, trophic character). To reveal soil patterns within broad landforms seems almost impossible without intensive sampling. 
Table 7. Variance by soil map units and soil taxons for 229 sites in the Assis region

\begin{tabular}{|c|c|c|c|c|c|c|c|c|c|c|c|c|}
\hline \multirow[b]{2}{*}{ Terrain } & \multirow[b]{2}{*}{ Altitude } & \multirow[b]{2}{*}{ SL } & \multicolumn{2}{|c|}{ Colour } & \multirow[b]{2}{*}{ Clay } & \multirow{2}{*}{$\begin{array}{c}\text { pH } \\
\text { KCl }\end{array}$} & \multirow[b]{2}{*}{ SB } & \multirow[b]{2}{*}{ CEC } & \multirow[b]{2}{*}{$\mathbf{m}$} & \multirow[b]{2}{*}{$\mathbf{V}$} & \multirow[b]{2}{*}{$\mathbf{C}$} & \multirow[b]{2}{*}{$\mathbf{P}$} \\
\hline & & & Hue & Chr & & & & & & & & \\
\hline & $\mathrm{m}$ & $\mathrm{cm} \mathrm{m} \mathrm{m}^{-1}$ & & & $\begin{array}{c}\mathrm{g} \mathrm{kg}^{-1} \\
0-20 \mathrm{~cm}\end{array}$ & & $-\mathrm{mmol}$ & $\mathrm{c} \mathrm{kg}^{-1}-$ & — & 6 & $\mathrm{~g} \mathrm{~kg}^{-1}$ & $\mathrm{mg} \mathrm{kg}^{-1}$ \\
\hline \multicolumn{13}{|l|}{ General statistics } \\
\hline Total variance & 4589 & 8 & 12 & 0.16 & $63.4^{(1)}$ & 0.33 & 1178 & 1617 & 115 & 342 & 38 & 493 \\
\hline Field variance & 213 & 4 & 7 & 0.10 & $3.4^{(1)}$ & 0.19 & 521 & 446 & 87 & 200 & 9 & 281 \\
\hline \% Var. explained & 95 & 46 & 41 & 38 & 95 & 43 & 56 & 72 & 24 & 42 & 77 & 43 \\
\hline \multicolumn{13}{|l|}{ log transformed data } \\
\hline Total Variance & . & 0.84 & 0.012 & 0.017 & 0.58 & 0.012 & 0.60 & 0.37 & 1.8 & 0.12 & 0.32 & 1.03 \\
\hline Field variance & . & 0.47 & 0.007 & 0.011 & 0.04 & 0.007 & 0.22 & 0.06 & 1.2 & 0.08 & 0.06 & 0.40 \\
\hline \% Var. explained & . & 44 & 42 & 35 & 93 & 42 & 64 & 83 & 37 & 34 & 81 & 61 \\
\hline \multicolumn{13}{|c|}{$\%$ of variance accounted for by soil map: } \\
\hline 2 map "orders" & 0 & $2^{\prime \prime}$ & 0 & 0 & 8 & 0 & 5 & 7 & $3^{(2)}$ & $0^{(2)}$ & 8 & $4^{(2)}$ \\
\hline 3 map "classes" & 4 & $16^{(2)}$ & 15 & 4 & 90 & 2 & 39 & 61 & $4^{(2)}$ & $0^{(2)}$ & 69 & $8^{(2)}$ \\
\hline 9 map "units" & 30 & $19^{(2)}$ & 15 & 18 & 95 & 7 & 48 & 69 & $15^{(2)}$ & $9^{(2)}$ & 73 & $36^{(2)}$ \\
\hline \multicolumn{13}{|c|}{ Pooled variance within map units } \\
\hline Variance & 3198 & $0.68^{(2 ;}$ & 10 & 0.13 & $3.3^{(1)}$ & 0.31 & 617 & 507 & $1.6^{(2)}$ & $0.11^{(2)}$ & 10 & 0.66 \\
\hline C.V. (\%) & 13 & $76^{(2)}$ & 11 & 11 & 13 & 11 & 51 & 32 & $150^{(2)}$ & $8^{(2)}$ & 26 & 33 \\
\hline \multicolumn{13}{|c|}{$\%$ of variance accounted for by soil taxons classified according to map legend criteria: } \\
\hline 2 soil "orders" & 0 & $1^{(2)}$ & 8 & 5 & 12 & 1 & 3 & 7 & $0^{(2)}$ & $2^{(2)}$ & 7 & $1^{(2)}$ \\
\hline 3 soil "classes" & 5 & $11^{(2)}$ & 20 & 8 & 89 & 1 & 31 & 53 & $2^{(2)}$ & $1^{(2)}$ & 63 & $8^{(2)}$ \\
\hline 7 soil "units" & 16 & $12^{(2)}$ & 19 & 13 & 94 & 14 & 43 & 62 & $21^{(2)}$ & $19^{(2)}$ & 68 & $13^{(2)}$ \\
\hline \multicolumn{13}{|c|}{ Pooled variance within taxonomic units } \\
\hline Variance & 3869 & $0.76^{(2 ;}$ & 9.4 & 0.14 & $3.6^{(1)}$ & 0.28 & 669 & 618 & $1.4^{(2)}$ & $0.10^{(2)}$ & 12 & $0.90^{(2)}$ \\
\hline C.V. (\%) & 14 & $80^{(2)}$ & 10 & 12 & $\begin{array}{c}14 \\
60-80 \mathrm{~cm}\end{array}$ & 10 & 53 & 35 & $145^{(2)}$ & $8 "$ & 28 & $39^{(2)}$ \\
\hline General statistics & & & & & & & & & & & & \\
\hline Total variance & & & 6 & 0.30 & $60.1^{(1)}$ & 0.49 & 554 & 538 & 753 & 667 & 0.11 & 17 \\
\hline Field variance & & & 4 & 0.18 & $2.1^{(1)}$ & 0.18 & 205 & 144 & 208 & 273 & 0.05 & 15 \\
\hline$\%$ Var. explained & & & 30 & 41 & 97 & 63 & 63 & 73 & 72 & 59 & 51 & 11 \\
\hline log transformed data & & & & & & & & & & & & \\
\hline Total variance & & & 0.005 & 0.017 & .38 & 0.021 & 1.29 & 0.271 & 3.5 & 0.54 & 28 & 0.40 \\
\hline Field variance & & & 0.004 & 0.009 & 0.02 & 0.007 & 0.29 & 0.049 & 1.1 & 0.19 & 9 & 0.30 \\
\hline \%Var. explained & & & 32 & 44 & 96 & 65 & 78 & 82 & 67 & 65 & 67 & 25 \\
\hline$\%$ of variance accoun & d for by soil & map: & & & & & & & & & & \\
\hline 2 map "orders" & & & 0 & 1 & 8 & 4 & 3 & 7 & $3^{(2)}$ & $0^{(2)}$ & 4 & $1^{(2)}$ \\
\hline 3 map "classes" & & & 12 & 17 & 89 & 45 & 45 & 56 & $46^{(2)}$ & $34^{(2)}$ & 41 & $12^{(2)}$ \\
\hline 9 map "units" & & & 13 & 20 & 96 & 56 & 53 & 62 & $60^{(2)}$ & $56^{(2)}$ & 43 & $19^{(2)}$ \\
\hline Pooled variance with & map units & & & & & & & & & & & \\
\hline Pooled unit var & & & 5.1 & 0.24 & $2.5^{(1)}$ & 0.21 & 261 & 204 & $1.4^{(2)}$ & $0.24^{(2)}$ & 6 & $0.33^{(2)}$ \\
\hline Pooled C.V. (\%) & & & 7 & 12 & 10 & 10 & 55 & 30 & $64^{(2)}$ & $13^{(2)}$ & 42 & $54^{(2)}$ \\
\hline$\%$ of variance accoun & d for by soil & taxons $\mathrm{cl}$ & assified & according & g to map & legend $\mathrm{cr}$ & criteria: & & & & & \\
\hline 2 soil "orders" & & & 7 & 4 & 6 & 1 & 1 & 3 & $1^{(2)}$ & $0^{(2)}$ & 5 & $0^{(2)}$ \\
\hline 3 soil "classes" & & & 16 & 22 & 86 & 39 & 33 & 44 & $39^{(2)}$ & $29^{(2)}$ & 43 & $11^{(2)}$ \\
\hline 7 soil "units" & & & 15 & 22 & 93 & 67 & 61 & 58 & $73^{(2)}$ & $70^{\prime \prime}$ & 43 & $12^{(2)}$ \\
\hline Pooled variance with & taxonomic & units & & & & & & & & & & \\
\hline Pooled unit var & & & 5.0 & 0.24 & $4.1^{(1)}$ & 0.16 & 217 & 228 & $0.93^{(2)}$ & $0.17^{(2)}$ & 6 & $0.36^{(2)}$ \\
\hline Pooled C.V. (\%) & & & 7 & 12 & 12 & 8 & 50 & 31 & $52^{\prime \prime}$ & $11 "$ & 42 & $56^{(2)}$ \\
\hline
\end{tabular}

(1) Multiply values by $10^{3}$. (2) Analysis performed after transformation to natural logarithm.

$\mathrm{ALT}=$ elevation above mean sea level. $\mathrm{SL}=$ slope. $\mathrm{SB}=$ sum of exchangeable bases. CEC =cation exchange capacity. $\mathrm{m}=$ aluminium saturation percentage $\left(100 \mathrm{Al}^{3+} /\left(\mathrm{SB}+\mathrm{Al}^{3+}\right) . \mathrm{V}=\right.$ base saturation percentage $(100 \mathrm{SB} / \mathrm{CEC}) . \mathrm{C}=$ organic carbon content. $\mathrm{P}=$ resin extractable phosphorus.

\section{Relation with spatial variability}

Comparison of our results with the results of Berg $\&$ Oliveira (2000) is possible since the same data were used and total variances mentioned in their tables 1, 2 and 3 also apply to this study. Variables with high within-field variance (e.g. soil colour in Araras) also have high within-soil-unit and withinmap-unit variance. As expected, the purity of soil map units tends to be smaller for these variables than for variables with low within-field variance (e.g. clay content), unless broad classes are used in the 
unit descriptions, such as for the trophic character in Araras. Within soil or map unit variance is generally larger than within field variance and semivariance at $1 \mathrm{~km}$ lag, especially for easily modified soil characteristics. This suggests that regular sampling at $1 \mathrm{~km}$ grids could result in isorithmic-maps with a better quality than the studied maps, but at considerable extra cost, since this would require 2.805 sampling sites for a sheet covering $55 \times 51 \mathrm{~km}^{2}$, whereas for the Araras map (Oliveira et al., 1982) only 493 sites were sampled for laboratory analysis.

\section{Possibilities for improvement of map quality}

Sometrends appeared in the purity analysis that could be used to the advantage of surveyors in future mappings, as an alternative to more intensive sampling:

- All samples of the 60-80 cm layer from Dusky Red Latosols in Araras and Assis had very fine clayey texture.

- Of all Dark Red Latosols, only two had very fine clayey texture.

- Of all observed clayey and very fine clayey Dusky Red Latosols and Dark Red Latosols only three were allic (one of which was profile 02 in table 5).

- Of all clayey and very fine clayey soils, only 12 were allic. Ten of thesesoilshad been mapped as Red Y ellow Podzolics and were situated in field 3 in Araras.

Descriptions of mapping units could be more precise and map purity could be improved if these considerations prove to be of general application for regions with similar soil formation conditions (geol ogy, climate, relief, vegetation/land use). It was shown that the maps were very successful with respect to the correct identification of soil texture classes. The combinations (Dusky Red Latosol + clayey) and (allic + clayey or very fine clayey) could simply be ignored in such regions. This needs validation, because the 395 augered sites were clustered in fields. Nevertheless, even if we consider fields as independent observations, having 17 fields with predominantly clayey and very fine clayey textured soils (seven in Araras, ten in Assis) of which only one has predominantly allic soils, gives a strong indication that the maps could be improved, e.g., by stating that strongly weathered clayey soils in the regions are usually not allic.

Another tool for soil mapping is the use of vegetation as a soil indicator. For example, Oliveira et al. (1981) statethat, in the Araras region, cerrado vegetation is strongly related with allic and dystrophic soils, but soils under forest can be dystrophic as well as eutrophic. Oliveira (1995) used the distribution of "bacuri" palms [Scheelea phalerata (Mart.) Burret], for the delimitation of eutrophic Dusky Red Latosols. Farmers don't cut these trees on their fields, because they form an evidence of good, valuable soil. As to our knowledge, no investigations have been undertaken so far, to quantify these relations.

It was shown by Berg $\&$ Oliveira (2000) that the major part of soil variability within distances smaller than $1.000 \mathrm{~m}$, is present within $50 \mathrm{~m}$ or even less. This short range variability could be removed by bulk sampling, by which each bulked sample is composed of samples from a small area, e.g., $10 \times 10 \mathrm{~m}^{2}$. This would make medium and long range patterns and correlations as suggested above more evident, and may possibly reveal medium range pedological structures.

As shown above, the studied soil maps are as good in separating land units as the classification system on which their legend is based, but taxonomic legend descriptions of mapping units do not correspond well with ground truth. For future mapping it may be wise to base map legends on what is actually being mapped rather than on the desireto makecomprehensive and consistent legends, based on taxonomic classes, with mutually exclusive definitions.

\section{Consequences for Land Evaluation}

It is obvious that the obtained results have important implications for using soil maps for land evaluation. The maps were very successful in separating and identifying areas with homogeneous soil texture, which is of great importance for land use. Problems arise with the land quality "soil fertility" or "nutrient availability", as reflected by thetrophic character $(\mathrm{m} \%, \mathrm{~V} \%)$, resin extractable $\mathrm{P}$ and organic $C$. Maps of both regions have a large within-unit variance for $\mathrm{m} \%, \mathrm{~V} \%$ and $\mathrm{P}$, especially in thesurfacelayer. The map of theAssis region has many impurities for the trophic character, whereas map units in the Araras region are very broadly described. The type of A horizon is an important aspect in land evaluation, but the criteria for identification are not uniformly applied. It would be justified to exclude the colour differentiation criterion in deep soils, which is al ready common practice in Brazilian surveys, because it is impracticableand probably disturbs correlation with soil suitability. Paradoxically, morethan half of the studied soils in Assis have A horizons with all aspects of prominent or chernozemic, except colour differentiation, but all soils had been mapped as having moderate A's. A check of field records of that survey suggests that not much attention had been given to this aspect.

It is quite possible that diagnostic properties of surface horizons were changed by management: liming may have increased base saturation; subsoiling may have increased the thickness of the A horizon and addition of sugarcane wastes may have increased the organic matter content (Camargo et al., 1983). In some case, A horizons that were originally moderate may have been transformed to 
prominent or chernozemic. Data presented by Oliveira (1995) and Lepsch et al. (1994) show that high-input agriculture may also affect subsurface horizons.

These considerations imply that "nutrient availability" cannot beinferred from soil maps al one. Additionally, one should use records of past management of individual fields to assess this land quality. In regions that have never been used for agriculture, soil maps may reflect the spatial variation of chemical soil characteristics better.

If crop yield models are used for land evaluation, it is clear that feeding the models with soil unit legends and data from "representative profiles" alone is not sensible. If model outcomes are approximately linearly related to soil variables, and if the variance is small, then "representative soil data" could be obtained by averaging. I $n$ other cases it is preferable to run the model many times over the observed ranges of attributes from numerous observations, after which an average result can be calculated and errors estimated.

\section{CONCLUSIONS}

1. Semi-detailed (scale 1:100.000) soil maps of the study regions contain useful information for regional land development, especially those involving agriculture with advanced management. The land quality "nutrient availability" cannot be inferred from soil maps alone, because it is very much influenced by past management, and analyzed maps either give very crude indications or have high impurities with respect to the trophic character.

2. Analysis of map purity and analysis of variance by mapping unit, when used in isolation, have limited value for the assessment of map quality. Together, they are very useful complementary techniques.

3. Soil surveyors should be more concerned about matching legends with what is actually being mapped rather than with taxonomic classification systems.

4. Feeding crop yield models with soil unit legends and data from "representative profiles" alone is not sensible.

5. Possibilities to improve quality of choropleth maps by bulk sampling and regional correlation between easily mappable land characteristics and difficult soil properties need to be explored.

\section{ACKNOWLEDGE MENTS}

The authors gratefully acknowledge the support of I nstituto Agronômico de Campinas (IAC), where the first author was a visiting scientist, and in special Dr. I.F. Lepsch, Dr. J .R.F. Menk and Dr. J .M.A.S. Valadares and the laboratories of the Sections of Pedology and of Soil Fertility and Plant Nutrition. We thank Usina São J õao in Araras, Cia. Agrícola Nova América in Assis, Capivara Agropecuária in Maracaí and coworkers and technicians of the "Cooperativa de Pedrinhas Pta" for logistic support during the field work on their properties; Hugo de Souza Dias, for providing accommodation on his lovely farm near Assis; J oão Hecke for support with profile descriptions; I.A. Bognola and A.C. J oaquim for access to the unpublished preliminary versions of the soil map of theAssis region; Dr. P.M. Driessen, of the laboratory of Soil Science and Geology of Wageningen Agricultural University and Prof. Dr. P.A. Burrough, of the Faculty of Geographical Sciences of Utrecht U niversity, for suggestions on earlier versions of the papers.

This study would not have been possible without a fellowship from the Netherlands Foundation for the Advancement of Tropical Research (WOTRO) and financial support of the Fundação para o Amparo da Pesquisa no Estado de São Paulo (FAPESP).

\section{LITERATURE CITED}

ARNOLD, R.W. Soil survey reliability: Minimizing the consumer's risk. In: NETTLETON, W.D.; HORNSBY, A.G.; BROWN, R.B. \& COLEMAN, T.L., eds. Data reliability and risk assessment in soil interpretations. Madison, Soil Science Society of America, 1996. p.13-20. (SSSA Special Publication, 47)

BECKETT, P.H.T. \& WEBSTER, R. Soil variability: A review. Soils Fertil., 34:1-15, 1971.

BERG, M. van den. Available water capacity in strongly weathered soils of southeast and southern Brazil. In: LATINAMERICAN CONGRESS OF SOIL SCIENCE: SOLO-SUELO, 13., Águas de Lindóia, 1996. (Extended Abstract on CD-ROM)

BERG, M. van den. Retenção de água nos solos tropicais fortemente meteorizados do Sul e Sudeste do Brasil. In: SIMPÓSIO DE HIDRÁULICA E RECURSOS HÍDRICOS DOS PAÍSES DE LÍNGUA OFICIAL PORTUGUESA (SI LUSBA), 3., Maputo, 1997. Anais. Maputo, 1997. v.2, t.2, p.1-10.

BERG, M. van den \& KLAMT, E. Variabilidade decaracterísticas de solos na região do planalto médio, RS: I. Análise da variância por amostragem aninhada. R. Bras. Ci. Solo, 21:393-399, 1997.

BERG, M. van den \& OLIVEIRA, J .B. Variability of apparently homogeneous soilscapes in São Paulo State, Brazil: I. Spatial analysis. R. Bras. Ci. Solo, 24:377-391, 2000.

BOGNOLA, I.A.; J OAQUIM, A.C.; PRADO, H.; LEPSCH, I.F.; MENK, J .R.F.; J AHEL, T.C.; SOARES, M.R.; MENEZES, F.D. \& NOGUEIRA, S.M. Plano Cartográfico do Estado de São Paulo. Carta Pedológica Semidetalhada do Estado de São Paulo: Assis. Secretaria Agricultura e AbastecimentoInstituto Agronômico/Secretaria E conomia ePlanejamentoIGC, 1996. Mapa escala 1:100.000. 
BREGT, A.K. \& WOPEREIS, M.C.S. Comparison of complexity measures for choropleth maps. Cartog. J ., 27:85-91, 1990.

BROWN, R.B.\& HUDDLESTON, J .H. Presentation of statistical data on map units to the user. In: MAUSCHBACH, M.J . \& WILDING, L.P., eds. Spatial variabilities of soils and landforms. Madison, Soil Science Society of America, 1991. p.127-147. (SSSA Special Publications, 28)

BURROUGH, P.A.; BECKETT, P.H.T. \& JARVIS, M.G. The relation between cost and utility in soil survey. I-III. J . Soil Sci., 22:359-394, 1971.

BURROUGH, P.A. \& MCDONNELL, R.A. Principles of geographical information systems. Oxford, Oxford University Press, 1998. 333p.

CAMARGO, O.A.; VALADARES, J.M.A.S. \& GERALDI, R.N. Características químicas e físicas de solo que recebeu vinhaça por longo tempo. Campinas, I nstituto Agronômico, 1983. 30p. (Boletim técnico, 76)

CAMARGO, M.N.; KLAMT, E. \& KAUFFMANN, J.H. Classificação de Sol os usada em Levantamentos Pedológicos no Brasil. Bol. Inf. SBCS, 12:11-33 e 70-71, 1986a.

CAMARGO, O.A.; MONIZ, A.C.; J ORGE, J .A. \& VALADARES, J .M.A.S. Métodos de análise química, mineralógica e física de solos do I nstituto Agronômico de Campinas. Campinas, Instituto Agronômico, 1986b. 94p. (Boletim técnico, 106)

EMPRESA BRASILEIRA DE PESQUISA AGROPECUÁRIA EMBRAPA. Sistema brasileiro de classificação de solos. Brasília, EMBRAPA Produção de informação; Rio de J aneiro, EMBRAPA Solos, 1999. 412p.

FAO. Guidelines for soil profile description. 2.ed. Rome, FAO, 1977. 50p.

FAO/UNESCO. Soil Map of the World, Revised Legend (reprinted with corrections). Rome, FAO, 1990. 119p. (World Soil Resources Report 60)

GRUIJ TER, J.J . \& MARSMAN, B.A. Transect sampling for reliable information on mapping units. In: NIELSEN, D.R. \& BOUMA, J ., eds. Soil spatial variability. Wageningen, Pudoc., 1985. p.150-165.

KONING, G.H.J . \& DIEPEN, C.A. van. Crop production potential of the rural areas within the European Communities. IV: Potential, water-limited and actual crop production. The Hague, Netherlands Scientific Council for Government Policy, 1992. 83p. (Working document, W68)

LEPSCH, I.F.; MENK, J .R.F. \& OLIVEIRA, J .B. Carbon storage and other properties of soils under agriculture and natural vegetation in São Paulo State, Brazil. Soil Use Manag., 10:34-42, 1994.

MANTEL, S. \& ENGELEN, V.W.P. van. The impact of land degradation on food productivity - Case studies of U ruguay, Argentina and Kenya: Main report. Wageningen, International Soil Referenceand I nformation Centre, 1997. 44p. (Report 97/01)

MARSMAN, B.A. \& GRUIJ TER, J .J . Dutch soil survey goes into quality control. In: BURROU GH, P.A. \& BIE, S.W., eds. Soil information systems technology. Wageningen, Pudoc, 1984. p.127-134.
MARSMAN, B.A. \& GRUIJ TER, J J . Quality of soil maps: a comparison of survey methods in a sandy area. Wageningen, Netherlands Soil Survey Institute (Stiboka), 1986. 103p. (Soil Survey Papers, 15)

OBERTHÜR, T.; DOBERMANN, A. \& NEUE, H.U. How good is a reconnaissance soil map for agronomic purposes? Soil Use Manag., 12:33-43, 1996.

OLIVEIRA, J .B. Solos da fol ha emunicípio de Guaíra. Campinas, Instituto Agronômico, 1995. 127p. (Boletim Científico, 33)

OLIVEIRA, J .B. \& BERG, M. van den. Aptidãoagrícola das terras do estado deSão Paulo: Quadrícula deAraras I., Campinas, Instituto Agronômico; Rio de J aneiro, I mpressão Aerofoto, 1983. Mapa 1:100.000.

OLIVEIRA, J .B. \& BERG, M. van den. Aptidãoagrícola das terras do estado de São Paulo: Quadrícula de Araras II. Memorial descritivo. Campinas, Instituto Agronômico, 1985. 60p. (Boletim Técnico, 102)

OLIVEIRA, J .B. \& BERG, M. van den. Relation between the Soil Units of the FAO-UNESCO Soil Map of the World Legend and the soil classes used in Brazilian surveys. Wageningen, International Soil Reference and Information Centre (ISRIC), 1996. 57p. (Technical Paper, 29)

OLIVEIRA, J.B. \& PRADO, H. Levantamento pedológico semidetal hado do Estado de São Paulo: Quadrícula de São Carlos, II. Memorial descritivo. Campinas, Instituto Agronômico, 1984. 188p. (Boletim técnico, 98)

OLIVEIRA, J .B.; MENK, J .R.F. \& ROTTA, C.L. Levantamento pedológico semidetal hado do estado de São Paulo: Quadrícula de Campinas. Rio deJ aneiro, IBGE, 1977. Mapa 1:100.000

OLIVEIRA, J .B.; MENK, J .R.F.; BARBIERI, J .L.; ROTTA, C.L. \& TREMOCOLDI, W.A. Levantamento pedológico semidetal hado do estado de São Paulo: Quadrícula de Araras. Rio de J aneiro, Aerofoto Cruzeiro, 1981. Mapa 1:100 000 .

OLIVEIRA, J .B.; BARBIERI, J .L.; MENK, J .R.F.; ROTTA, C.L. \& TREMOCOLDI, W.A. Levantamento pedológico semidetalhado do Estado de São Paulo: Quadrícula de Araras. Campinas, Instituto Agronômico, 1982. 180p. (Boletim Técnico, 71)

OLIVEIRA, J.B.; J ACOMINE, P.K.T. \& CAMARGO, M.N. Classes gerais de solos do Brasil: Guia auxiliar para seu reconhecimento. J aboticabal, FUNEP, 1992. 201p.

PRADO, H.; OLIVEIRA, J .B. \& ALMEIDA, C.L.F. Levantamento pedológico semidetal hado do estado de São Paulo: Quadrícula deSão Carlos. Rio deJ aneiro, Aerofoto Cruzeiro, 1981. Mapa 1:100.000.

RAIJ , B. van \& QUAGGIO,J .A. Métodos de análise de sol o para fins de fertilidade. Campinas, Instituto Agronômico, 1983. 31p. (Boletim técnico, 81)

SOIL SURVEY STAFF. Soil Survey Manual. Washington D.C., United States Department of Agriculture, 1951. 503p. (Agric. Handbook, 18)

SOIL SURVEY STAFF. Soil Survey Manual. Washington D.C., United States Department of Agriculture, 1993. 1993. 437 p. (Handbook, 18) 
RÖTTER, R. \& DREISER, C. Extrapolation of maize fertilizer trial results by using crop-growth simulation: results for Murang'a district, Kenya. In: FRESCO, L.O.; STROOSNIJ DER, L.; BOUMA, J . \& KEULEN, H. van, eds. The future of the land, mobilising and integrating knowledge for land use options, Chichester, J ohn Wiley \& Sons, 1994. p.249-260.

SOUZA DIAS, H. Mapeamento de solos da C.A.N.A. Assis, Cia. Agrícola Nova América, 1985. Mapa 1:50.000
SYSTAT INC. Systat, the system for statistics. version 2 . Evanston, Systat Inc., 1985.

WEBSTER, R. \& OLIVER, M.A. Statistical methods in Soil and Land Resources Survey. Oxford, Oxford University Press, 1990. 316p.

WILDING, L.P. \& DREES, L.R. Spatial variability: A pedologist's viewpoint. In: STELLY, M.; KRAL, D.M. \& NAUSEEF, J .H., eds. Diversity of soils in the tropics. Madison, Soil Science Society of America, American Society of Agronomy, 1978. p.1-12. (ASA Special Publication, 34) 
